DOI 10.37882/2223-2982.2021.10-2.10

\title{
СЛЕНГИЗМЫ КАК СПОСОБ СОХРАНЕНИЯ НАЦИОНАЛЬНОЙ ИДЕНТИЧНОСТИ (НА МАТЕРИАЛЕ МЕКСИКАНСКОГО МОЛОДЕЖНОГО СЛЕНГА)
}

\section{SLANGISMS AS A WAY TO PRESERVE NATIONAL IDENTITY (BASED ON THE MATERIAL OF MEXICAN YOUTH SLANG) \\ N. Zenenko L. Son}

Summary: Globalization, no matter what positive results it gives, is becoming one of the causes of the crisis of national identity. The deglobalization processes that are replacing globalization create conditions for the activation of linguistic means that can ensure the ethnic identity of the state. Language, being the core of society, is able to preserve the cultural, intellectual and spiritual roots of the nation. In this article, Internet communication and slangisms are considered as a tool for protecting the peculiarities of the Mexican national language culture.

Keywords: slangisms, national identity, globalization, de-globalization, internet communication.
K онец XX - начало XXI вв. ознаменовался новым явлением общественно-исторического развития человечества, получившим название «глобализация». Современному развитию мирового устройства присуща высокая степень интеграционных процессов практически во всех сферах жизнедеятельности человека. Глобализация, приводя к наднациональной интеграции, в результате наносит удар идентичности нации.

Глобализация - это «сложный многомерный процесс, проявляющийся в экономической, политической, информационной и культурной универсалиях, когда территориальность исчезает как организующий принцип социальной и культурной жизни» [2].

Не секрет, что в основе глобализации - англо-американская модель развития социума, его политики, экономики и культуры, которая активно проецируется на английский язык.

Взаимодействие мировых языков, которое теоретически должно происходить на паритетной основе, является характерной чертой периода глобализационных процессов, однако, как показывает практика, английский язык претендует на главенствующую роль среди других национальных языков, подавляя тем самым этническую идентичность нации, у которой английский язык
Зененко Наталья Викторовна

Д.фил.н., профессор, Военный университет Министерства обороны РФ (2. Москва) zenenko@mail.ru

Сон Людмила Петровна

К.э.н., доцент, Военный университет Министерства обороны РФ (2. Москва) luciason@mail.ru

Аннотация: Глобализация, какие бы положительные результаты она ни давала, становится одной из причин кризиса национальной идентичности. Деглобализационные процессы, которые приходят на смену глобализации, порождают условия для активизации языковых средств, способных обеспечить этническую самобытность государства. Язык, будучи стержнем социума, способен сохранить культурные, интеллектуальные и духовные корни нации. Интернет-коммуникация и сленгизмы в данной статье рассматриваются в качестве инструмента защиты особенностей мексиканской национальной языковой культуры.

Ключевые слова: сленгизмы, национальная идентичность, глобализация, деглобализация, интернет-коммуникация.

не является национальным. Подобные языковые процессы не могут не оказывать влияния на самосознание нации, поскольку, по мнению В. Фон Гумбольдта, «язык тесно переплетен с духовным развитием человечества и сопутствует ему на каждой ступени его локального прогресса или регресса, отражая в себе каждую стадию культуры» [1].

Неизбежно в определенный период исторического развития перед каждой нацией встает дилемма - сохранение или потеря национальной идентичности.

Известно, что доктрина «язык - фундамент общества» сформировалась еще в эпоху Возрождения. Значительная часть информации приходит к человеку по лингвистическому каналу. Каждый естественный язык, используя собственный языковой ресурс, способен удовлетворить им же созданные интеллектуальные, духовные, социальные потребности.

Чрезмерное влияние английского языка на другие национальные языки вызывает серьезное беспокойство среди философов, культурологов, психологов, социологов и лингвистов. Исходя из тезиса В. Фон Гумбольдта, что «... язык народа есть его дух», следует считать язык средством выражения духовности, мировоззрения, мироощущения народа, в котором хранятся «... интеллек- 
туальные духовные гены», переходящие из поколения в поколение. Доминирующее положение английского языка в мире может оказать мощное воздействие на национальную культуру и язык, и стать одной из причин кризиса национальной идентичности.

Актуальность темы национальной идентичности в отечественном языкознании подтверждается наличием исследований, посвященных изучению национального самосознания [Серебренников 1988, Колшанский 1990, Леонтьев 1993, Арутюнова 1999, Тер-Минасова 2004 и др.].

Ученые солидарны в том, что индивид ощущает необходимость и важность понимания своей национальной или этнической принадлежности. Материальные и культурные компетенции нации создают платформу для формирования национальной идентичности, сущностное начало которой состоит в осознании «нации как связного целого, представленного уникальными традициями, культурой и языком» [5]. Сохранение национальной идентичности, богатства культуры и языка является первостепенной задачей каждого народа. Представляется, что возможности для реализации этой весьма сложной задачи существуют.

Диалектика мирового исторического развития демонстрирует процесс обратный глобализации - деглобализацию: страны вновь обретают суверенитет и готовы к принятию самостоятельных и независимых решений [Grexit (Greece Exit); Brexit (Britain Exit)]. Глобальная эпидемиологическая ситуация и, как следствие, пандемия COVID-19, обязали весь мир играть «по своим правилам» и, тем самым, запустили процессы де-глобализации. В контексте сохранения идентичности нации представляется, что процессы де-глобализации создают оптимальные условия для достижения данной цели. Ввиду невозможности/затруднения общения в реальной среде, коммуникация (письменная и устная) локализуется в виртуальном пространстве - в сети Интернет, обладающей огромным ресурсом обеспечения общения индивидов онлайн. Язык превращается в мощный инструмент для продвижения интересов отдельного этноса и сохранения национальной идентичности.

Важнейшая сфера функционирования языка - это устная коммуникация, основой которой является разговорный язык. Представляется важным в данном контексте определение понятию «разговорный язык», сформулированное Ю.М. Скребневым: «Разговорный язык - это в некотором смысле минимальная система национального языка, филогенетически и онтогенетически первичная система, важнейшая по диапазону общественной и индивидуальной значимости» [3].

Неотъемлемой частью любого естественного языка в его разговорной форме является сленг. Известно, что в значительной степени сленг опирается на культурный опыт языка - в нем нередко можно встретить не только традиционные, исторические, фольклорные, но и литературные слова-заимствования, свойственные данному стилю языка, которые приобретают особую экспрессию, не теряя при этом национального колорита.

Проблеме изучения сленга посвящены исследования О.С. Ахмановой, И.Р. Гальперина, П.А. Горшкова, Л.А. Зениной, Ю.В. Коноплевой, Ю.М. Скребнева, А.И. Смирницкого, Ю.Н. Пинягина, В.А. Хомякова, Х. Менкена, Э. Партриджа, Э. Раймонда, К. Эбл, С. Флекснера и других ученых.

В настоящее время существуют разные точки зрения о происхождении сленга, однако, ученые проявляют единодушие в понимании того, что живой язык, в том числе и «язык улицы», язык обычных носителей языка существует в непрерывной коммуникативной динамике, выполняя при этом одну из его главных функций - быть средством общения. А это значит, быть способным передавать, обрабатывать и хранить информацию, причем этот процесс релевантен не только для нормы литературного языка, но и для нестандартного национального языка, в нашем исследовании - сленга.

Известно, что самые активные пользователи Интернета - это молодежная аудитория, осуществляющая коммуникацию в многочисленных социальных сетях и чатах, их общение наполнено сленгизмами, присущими национальному варианту любого естественного языка. В нашем исследовании мы остановимся на описании характеристик сленгизмов мексиканского национального варианта испанского языка, которые участвуют в формировании образа страны и ее жителей. Важно отметить, что сленгизмы в большом количестве присутствуют в процессе коммуникации онлайн. Мексиканские интернет-пользователи, тем самым, хранят и популяризируют национальную языковую культуру.

Известно, что началу любого общения предшествует приветствие. Так, житель Мексики задаст традиционный для мексиканской лингвокультуры вопрос ¿qué onda? (дословный перевод - как волна?). Этот вопрос является риторическим и, несмотря на свое значение (как дела?), не требует ответа и воспринимается реципиентом как желание коммуниканта обратить на себя внимание и, возможно, продолжить общение. Например: "iHola, amigo! ¿Qué onda? ¿Todo bien?" (исп.) - Привет, дружище! Как оно? Все хорошо? (русск.).

Следует обратить внимание в этой связи на использование сленговых форм при обращении. Так, например, в мексиканском сленге существует слово gӥеу или wey (мекс. исп.). В русском языке наиболее близкое по значению - чувак (русск.). Сленгизм gӥеу в мексиканском 
варианте современного испанского языка используют в качестве обращения и к мужчине, и к женщине. Стилевой характеристикой данной лексемы является ее применение не только в диалоге между друзьями, но и в беседе с малознакомыми людьми разных возрастных групп. Этот факт является свидетельством проявления коммуникабельности как особенности национального характера жителей Мексики.

В составе мексиканского сленга не менее интересно и многозначно употребление лексемы ¡Órale! Специфика этой сленговой формы заключается в том, что к ней невозможно подобрать определённое значение, поскольку оно зависит только от контекста дискурса и может переводиться, например, как ладно, хорошо, серьезно?, уnс!, класс, давай! (русск.) и т.д. В этой связи мексиканцы шутят, что данное слово обладает бо́льшим количеством значений, чем кактус иголками. Отмечается широкое использование данного сленгизма в виртуальной коммуникации. В зависимости от контекста и стилевых рамок, сленгизм ¡Órale! может передавать разные эмоциональные состояния участников коммуникации. Например, в высказывании: ¡Órale! Así es. Haces todo correcto (исп.) - Да, так и нужно. Ты все делаешь правильно (русск.) - говорящий выражает чувство одобрения. А в реплике: ¡Órale! Vamos al cine con nosotros (исп.) - Давай! Пойдем в кино с нами (русск.) чувство воодушевления. Также данный сленгизм может выражать сомнение - ¡Órale! ¿Gano la lotería? (исп.) - He может быть! Выиграл в лотерею? (русск.) или согласие собеседника - Órale, compraré este coche. Pero me lo debes por eso (исп.) - Ладно, я куплю эту машину. Только ты мне будешь должен (русск.).

Итак, можно отметить, что сленговая форма ¡Órale!, активно используясь участниками коммуникации, становится маркером мексиканской лингвокультуры.

Мексиканский сленг обладает большим количеством междометий, многие из которых представляют собой ментефакты, связанные с историей Мексики. Показательно, в связи с этим, использование в разговорной речи междометия ¡Aguas! (исп.) - вода (русск.). Истоки этого выражения кроются в колониальном периоде истории Мексики. В стране отсутствовала система водоотвода, и все отходы выливались на улицу прямо из окна. Прежде чем произвести это действие, во избежание штрафа, человек должен был предупредить проходящих под окнами об опасности, используя междометие ¡Aguas!

Жители современной Мексики используют в речи данное междометие для предупреждения о любой надвигающейся опасности. Например: ¡Aguas! ¿A dónde corres? ¿No veas que es la ruta para los camiones? (исп.) Осторожно! Куда бежишь? Не видишь, что эта дорога для автобусов? (русск.). ¡Aguas! No te comuniques con Paco.
Es un ladrón (исп.) - Будь осторожен! Не связывайся с Пако. Он вор (русск.).

Анализируя мексиканские сленговые формы, следует обратить внимание на некоторые способы образования сленгизмов. В частности, префиксальный способ, с помощью которого, к примеру, образовалось существительное desmadre посредством слияния предлога de и существительного женского рода единственного числа madre, что в переводе на русский язык означает полная катастрофа, несчастье, провал и т.д. Например: Es desmadre, necesitas un 5 en el examen final (исп.) - Это полная катастрофа, мне нужно получить 5 по итоговому экзамену (русск.).

Самобытно создание выражения ¡Chócala cinco! (исп.) - Дай пять! (русск.). Данное выражение в разговорной речи молодежи чаще употребляется в усеченной форме ¡Chócala! (исп.). Этот сленгизм образовался путем сочетания повелительного наклонения глагола chocar (исп.) - столкнуться, врезаться, ударить (русск.) и числительного cinco (исп.) - пять (русск.). Например: Esta idea es maravillosa! Chócala! Quería proponer lo mismo! (исп.) - Это потрясающая идея! Дай пять! Я хотел предложить тоже самое! (русск.).

В контексте использования сленгизмов в качестве инструмента сохранения идентичности нации, представляется уместным упомянуть о наличии автохтонных языков в мексиканском варианте испанского языка. Вслед за Г.В. Степановым, мы считает важным рассматривать язык как совокупность видов вариативности [4]. В связи с тем, что индейские языки (впрочем, как и большинство автохтонных языков) являются языками, не имеющими письменности, т.е. в основном использующиеся в устной речи, автохтонные мексиканизмы нередко квалифицируются как сленгизмы.

Современные мексиканские лингвисты считают, что исчезновение лексем из автохтонных языков Мексики приведет к возникновению лингвистического хаоса [7].

Сложно не согласиться с позицией ученых, поскольку «хлеб насущный» мексиканской кухни составляют слова, произошедшие из науатля. Например: enchiladas (мекс. исп.) - энчиладас (русск.), chilaquiles (мекс.исп.) - чилакилес (русск.), mole (мекс.исп.) - моле (русск.), chimóle (мекс.исп.) - чимоле (русск.), pozole (мекс.исп.) - посоле (русск.), atole (мекс.исп.) - атолле (русск.), guacamole (мекс.исп.) - гуакамоле (русск.), tamale (мекс.исп.) - тамале (русск.) и др.

Мексиканский лингвист Давил Гариби $[6,113]$ считает, что мексиканцы активно используют в диалогической речи некоторые индехинизмы, т.к. они вытеснили эквивалентные испанские лексемы из мексиканского национального варианта языка. Так, по его мнению, от- 
мечается наличие большого количества слов и выражений, пришедших в испанский язык Мексики из науатля (Науатль - один из индейских языков, оказавший влияние на испанский язык Мексики (прим. авт.).). Например, слово ререnar (мекс.исп), пришло из науатля и означает выбрать, подобрать что-либо, разбросанное на полу (русск.).

Мексиканские индехинизмы активно используются в интернет-коммуникации, и сленг можно рассматривать в качестве проводника автохтонных языков Мексики в глобальную Сеть.

На основании вышесказанного мы пришли к выводу о том, что сложившаяся эпидемиологическая ситуация привела к активной интернет- коммуникации, вследствие чего Интернет становится идеальной платформой для продвижения лингвистических интересов этноса и сохранения национальной идентичности, а сленг используется в качестве его инструмента.

\section{ЛИТЕРАТУРА}

1. Гумбольдт В. фон. Избранные труды по языкознанию: пер. с нем. / общ. ред. Г.В. Рамишвили. - М.: ОАО ИГ «Прогресс», 2000. - 400 с.

2. Миронов А.В. Социально-гуманитарное образование сегодня: проблемы и перспективы // Социально-гуманитарные знания. - 2001. - № 3. - С.13.

3. Скребнев Ю.М. Введение в коллоквиалистику / под ред. 0.Б. Сиротининой. - Саратов, 1985. - С. 87.

4. Степанов Г.В. Типология языковых состояний и ситуаций в странах романской речи. М.: Наука, 1976. - С. 93.

5. Искусство и цивилизационная идентичность / отв. ред. Н.А. Хренов. - М.: Наука, 2007. - 603 С.

6. Garibi Dávila J.I. Del Náhuatl al Español. Instituto Panamericano de Geografía Historia, Tacubaya D. F. 1939. - P. 112-114.

7. Ureña P.H. Observaciones Sobre el Español de México // Estudios mexicanos. Fondo de Cultura Economica. México, 2012. - P. 47, 167.

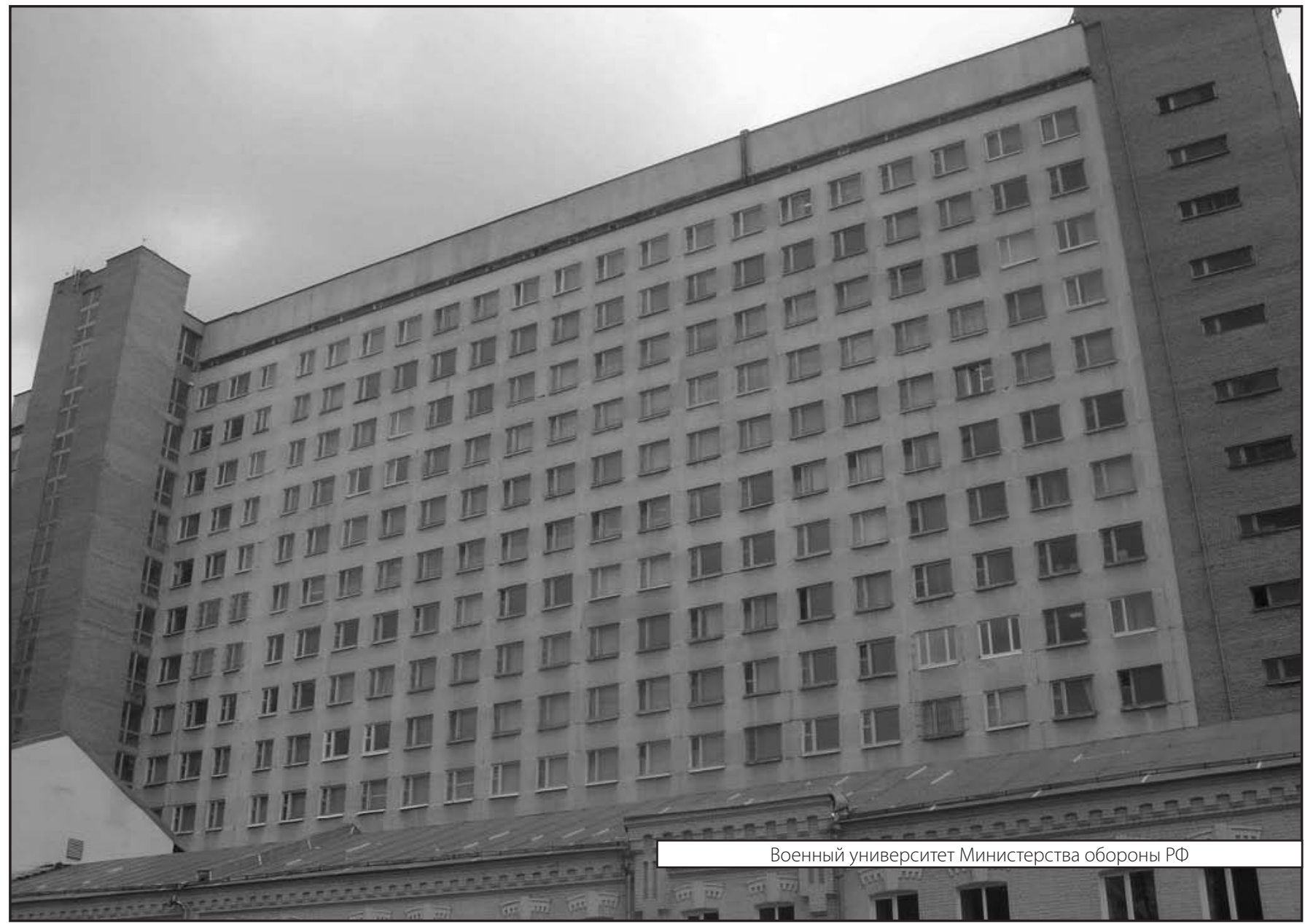

